\title{
Learning to Live Through Loss: Understanding Men Who Grieve ${ }^{1}$
}

Carolyn S. Wilken ${ }^{2}$

The only cure for grief is to grieve.

\author{
-Joshua Loth Leibman
}

It is difficult to watch someone you care about grieve and hurt. It is even more difficult and confusing when that person grieves in a way you don't understand. Sometimes men's grief differs from women's. It's not less effective or less appropriate. It is simply different. While women tend to react to the loss of a loved one as abandonment, men perceive it as losing part of themselves, as if severing an arm or leg.

Understanding the differences will help you empathize and reach out to the man who mourns. To learn more about the process of mourning, read the extension publication Learning To Live Through Loss: Grief and the Mourning Process, (FCS2267) available from your Extension office or at http://edis.ifas.ufl.edu/FY881.

"I didn't let anyone see me cry," comments Curtis, whose wife died of cancer. "Actually, I did my best not to cry at all."

\section{Men React Differently to Loss}

In our society, many men find it difficult to express their personal feelings and needs. The natural need to talk about one's grief may conflict with the traditional belief that a man must always be in control of his emotions. Many men find it difficult to show their grief around others. Friends and family may think "He's over it" when, in fact, he is still hurting.

Many men try to distract themselves with their jobs. They strongly desire to maintain productivity and are often discouraged when, quite normally, they have less energy and less attention to give their work because of their grief.

Often men prefer to take action instead of confronting their feelings. They may increase their physical activity or over commit themselves to employment or community service. Many men feel a sense of failure because they cannot control the situation. They could not prevent the death. They could not protect the loved one who died.

"No matter what I do," Curtis explains, "no matter how much I work, or how busy I

1. This document is FCS2266, one of a series of the Department of Family, Youth and Community Sciences, Florida Cooperative Extension Service, IFAS, University of Florida, Gainesville FL 32611. First published: November 2006. Please visit the EDIS Web site at http://edis.ifas.ufl.edu. Originally published in 1994 by Kansas State University CES.

2. Carolyn S. Wilken, PhD, M.P.H., associate professor, Department of Family, Youth and Community Sciences, Florida Cooperative Extension Service, IFAS, University of Florida, Gainesville FL 32611. We would like to thank Cheryl Bailey, LMHC, Haven Hospice of North Central Florida, for her comments and suggestions. 
am, I still go to bed alone. I can't bring her

back. I can't fill the hole her death left in my life."

\section{Men Who Lose A Spouse}

When a man loses his wife, he usually loses his best friend and confidante. The person he could talk with-who could help heal his grief just by listening-is gone. Understandably, men seem to have more health problems and are more likely to commit suicide than women during their first year of widowhood.

\section{Some Truths About Widowers}

- Men do feel lonely, even if they act "strong."

Loneliness, grief, and the pressures of running a household create very real crisis for men.

- People don't contact widowers as frequently as widows, even though the widower's need for companionship is often greater. Sometimes people don't know what to say.

- Even couples who had been friends before the death may stop inviting the widower to their homes. Awkwardness becomes a social barrier.

- Sexual frustration may be a concern. Yet many men feel guilty about needing sexual release, as if they were "cheating" on their dead spouses.

\section{Becoming A Single Father}

Some men lose more than their best friend; they lose a nurse, a household manager, a child care expert, a chef, and so on. Men who have invested themselves primarily in their occupations may experience sudden shock at becoming a single parent. These men may need specific,

practical information about how to manage their new roles. A basic cookbook, help in finding child care and coaching in housecleaning techniques can help.

Finding a new family routine will take time. It is important that the new single father not expect too much of children or adolescents. No child should feel that he or she must replace the lost spouse. And the children need to grieve the loss of their mother. To learn more about children's grief, see the Extension publications "For Teens Facing Loss” (FCS2265) (http://www.edis.ifas.ufl.edu/FY879) and "Helping Children Understand Death" (FCS2263) (http://www.edis.ifas.ufl.edu/FY877). It is important to be realistic about the parent's and the children's needs and abilities. Look for resources in your community to supplement or build family strengths.

\section{Men Who Lose a Child}

Fathers who have lost a child may feel left out of the mourning process. People tend to show concern for the mother and other children and ask how they are doing. Few ask about the father. Men also need recognition of their loss and an invitation to talk about their experiences.

Different grieving styles can strain the marriage relationship. Often a father seeks refuge in his work and keeps his feelings hidden. The father may not even mention the child's name for fear of upsetting his wife. But his wife, believing he doesn't care, may feel emotionally abandoned and resentful of his seemingly cold response. 
Struggling marriages sometimes end in divorce after the death of a child.

Differences in grieving can interfere with already strained communication. Spouses may blame each other, blame themselves or misdirect their anger at other children.

Making allowances for different ways of grieving can help the marriage survive the death of a child. So can seeking comfort and support from friends instead of looking solely to the spouse. When the father talks about the death and his experience, generally the whole family opens up. Talking as a family can be the beginning of healing, accepting the death and strengthening the family.

\section{How to Help the Man Who Grieves}

- Give him the freedom to have feelings and express them with whom he chooses.

- Reassure him emotions are normal and talking about them is necessary and healthy.

- Give him the freedom to be silent, as well. Your presence and acceptance will help him express his grief in the ways best for him.

- Encourage activity as a part of confronting grief. Physical labor is one way to channel powerful emotions. Find an activity you can do together. Some men find it easier to talk while working together.

- Remember it may be easier for him to talk about his experience in the context of his family and their reactions. Spotlighting his feelings may seem threatening.
- Become aware of his practical needs and provide support.

\section{Some Ideas for the Widowed Father}

- Provide him with resources or information that can help in household management and parenting. Offer to work with him to find child care.

- Invite the family to your home to cook together, relieving him of responsibility for one night and giving him the opportunity to learn to cook a new dish.

\section{Some Ideas for the Grieving Father}

- Ask about him. Invite him to talk about his experiences.

- Offer to babysit the other children for a weekend so the couple can take time to be together.

People tend to rush in to help during the first few weeks. Later they drop their support because they feel they are interfering or because they want to get back to their usual routine. Grief lasts longer than a few weeks. Continue to find ways to offer emotional and practical support. Be a friend. Encourage others to do the same.

\section{Publications to Recommend to the Bereaved Man}

Living When a Loved One Has Died by Earl Grollman. Beacon Press, Boston.

This is a moving book of photographs and comments from a man who has experienced grief.

The Widower by Jane Burgess Kohn and Willard K. Kohn. Beacon Press, Boston. Two widowers write about many concerns, 
from surviving to building a new life in this realistic, yet personal book.

Learning to Live Through Loss: Grief and The Mourning Process, FCS2267, by Carolyn S. Wilken. This resource is available through local Extension offices or at http://edis.ifas.edu/FY881.

\section{References}

DeFrain, John, Taylor, Jacque, and Ernst, Linda. Coping with Sudden Infant Death. Lexington, MA: D.C. Heath, 1982.

Knapp, Ronald J. Beyond Endurance: When a Child Dies. New York: Schocken Books, 1986.

Kohn, Jane Burgess and Willard K. Kohn. The Widower. Boston: Beacon Press, 1978.

Nardi, Peter M. (Ed) Men's Friendships.

Newbury Park: Sage Publications, 1992.

Rando, Therese. Grieving: How to Go on Living When Someone You Love Dies. Lexington: D.C. Heath and Company, 1984.

Sanders, Catherine M. Grief: The Mourning After. New York: John Wiley \& Sons, 1989.

Stroebe, Wolfgang and Margaret S. Stroebe. Bereavement and Health. Cambridge:

Cambridge University Press, 1987. 